\title{
Supplementation of Jengkol Peel on VFA Molar Proportion, Methane Production, and Hydrogen Balance in Vitro
}

\section{Pengaruh Suplementasi Tepung Kulit Jengkol (Archidendron jiringa) pada Proporsi Molar VFA, Produksi Metan, dan Keseimbangan Hidrogen In Vitro}

\author{
N. Hidayah ${ }^{1 *}$, Nurhaita ${ }^{2}$,W. Rita ${ }^{2}$, and R. Zurina ${ }^{2}$ \\ ${ }^{1}$ Agricultural Faculty, Tidar University, Magelang, 56116 - Indonesia \\ ${ }^{2}$ Agricultural Faculty, Bengkulu Muhammadiyah University, Bengkulu, 38119 - Indonesia \\ *Corresponding E-mail: nurhidayah@untidar.ac.id \\ (Diterima: 14 Januari 2020; Disetujui: 3 Maret 2020)
}

\begin{abstract}
This research was designed to study about effects of supplementation jengkol (Archidendron jiringa) peel powder on VFA molar proportion, production of methane, and hydrogen balance in vitro. The experiment used randomized block design with 4 treatments $(0 \%, 2 \%, 4 \%, 6 \%)$ and 4 replications. The research observed of VFA molar proportion, production of methane, and hydrogen balance. Data were analyzed using Analysis of Variance (ANOVA), and the Duncan Multiple Range Test examined the differences among treatment means. The results showed that the supplementation of jengkol $(A$.jiringa $)$ peel powder until $6 \%$ did not affect $(\mathrm{P}>0.05)$ VFA molar proportion but the treatment without supplementation of jengkol $(A$. jiringa) peel powder had the highest $(\mathrm{P}<0.05)$ methane and $\mathrm{H} 2$ production. It was concluded that the supplementation of jengkol ( $A$. jiringa) peel powder until $6 \%$ decreased methane and hydrogen production but did not affect on VFA molar proportion.
\end{abstract}

Keywords: jengkol peel powder, methane, VFA molar proportion

\section{ABSTRAK}

Penenelitian ini bertujuan untuk mengecaluasi pengaruh suplementasi tepung kulit jengkol (Archidendron jiringa) pada proporsi molar VFA, produksi metan, dan keseimbangan hidrogen in vitro. Rancangan penelitian menggunakan rancangan acak kelompok, 4 perlakuan suplementasi (0\%, 2\%, 4\%, 6\%) dan 4 ulangan. Variabel yang diamati meliputi proporsi molar VFA, produksi metan, dan keseimbangan hidrogen. Data dianalisa menggunakan ANOVA dan perbedaan perlakuan diuji lanjut dengan uji DMRT. Hasil penelitian melaporkan, suplementasi tepung kulit jengkol (A. jiringa) sampai 6\% tidak berpengaruh $(P>0,05)$ pada proporsi molar VFA tetapi perlakuan kontrol (tanpa suplementasi kulit jengkol) paling tinggi produksi metan dan $\mathrm{H}_{2}$ nya. Kesimpulannya yaitu suplementasi tepung kulit jengkol (A. jiringa) sampai 6\% menurunkan produksi metan dan hidrogen tetapi tidak mempengaruhi proporsi molar VFA.

Kata kunci: tepung kulit jengkol, metan, proprosi molar VFA

\section{INTRODUCTION}

Many researchers reported that bioactive compound tannin and saponin can reduced methane production and increased livestock productivity (Jayanegara et al., 2011; Holtshausen et al., 2009). Jengkol (Archidendron jiringa) is a tropical plant Southeast Asian typical that contain tannin and saponins. In Indonesia, Jengkol widely grown in the western part, particularly in Bengkulu Province, Sumatera island as much 2,822 tons in 2017 (BPS, 2018). During this time the fruit was used as food and medicine, but until now there are not much information regarding to the utilization of Jengkol byproduct (peel and leaves) as feed supplement. Jengkol has potency as a feed supplement because its 
Table 1. VFA molar proportion (\%)

\begin{tabular}{lrrrr}
\hline \multirow{2}{*}{ Parameter } & \multicolumn{4}{c}{ Jengkol Peel Powder (\%) } \\
\cline { 2 - 5 } & \multicolumn{1}{c}{0} & \multicolumn{1}{c}{ 2 } & \multicolumn{1}{c}{6} \\
\hline Acetate (\%) & $73.64 \pm 3.36$ & $73.49 \pm 3.50$ & $68.77 \pm 3.90$ & $75.86 \pm 4.24$ \\
Propionate (\%) & $13.84 \pm 0.47$ & $14.42 \pm 1.02$ & $14.90 \pm 0.84$ & $12.88 \pm 2.00$ \\
Butirat (\%) & $7.19 \pm 2.23$ & $7.56 \pm 1.21$ & $8.45 \pm 1.20$ & $6.37 \pm 1.54$ \\
Valerat (\%) & $5.48 \pm 1.24$ & $5.66 \pm 0.74$ & $7.87 \pm 2.32$ & $4.88 \pm 0.71$ \\
A : P & $5.32 \pm 0.39$ & $5.04 \pm 0.57$ & $4.64 \pm 0.51$ & $6.02 \pm 1.26$ \\
\hline
\end{tabular}

good nutrition. According to (Hidayah et al., 2019) showed that jengkol peel contains $C P$ (8.83\%), CF (27.50\%), saponin (56.92\%), and tannin $(7.82 \%)$.

Saponin are secondary compounds that have protozoa defaunate effect, stimulate growth of rumen bacteria, and decrease methanogenesis. Wina et al. (2005); Wanapat et al. (2013) reported that saponins have been strong defaunation properties which could reduce methane production on in vitro and in vivo. Therefore, objective of this research to study about effects of supplementation jengkol (Archidendron jiringa) peel powder on VFA molar proportion, production of methane, and hydrogen balance in vitro.

\section{METHODS}

\section{Preparing Materials}

Forage and jengkol peel were sun dried until getting stable weight. After that, the materials were grinded with machine to form powder.

\section{In Vitro Fermentation}

The in vitro method according to the Tilley and Terry (1963). Into each $100 \mathrm{~mL}$ fermentation tube, $10 \mathrm{~mL}$ rumen fluid, 40 $\mathrm{mL}$ McDougall buffer, and $500 \mathrm{mg}$ substrate were added at $39^{\circ} \mathrm{C}$. The rumen fluid from 3 rumens fistulated Ongole crossbred beef cattle with Ethical Approval from Animal Care and Use Committee (AUAC) 01-2013b LIPI Cibinong. VFA analysis was taken from sample that were $4 \mathrm{~h}$ incubation.

\section{Sampling and Measurement}

VFA molar proportion were analyzed using gas chromatography with capillary column type containing 10\% SP-1200, 1\% H3PO4 on $80 / 100$ Cromosorb WAW and nitrogen as gas catirrier. Methane production was estimated from molar proportions of VFA according to Moss et al. (2000) $(\mathrm{CH} 4=0.45$ $\mathrm{C} 2-0.275 \mathrm{C} 3+0.40 \mathrm{C} 4$ ), and hydrogen balance was estimated from VFA molar proportion according to Mitsumori et al. (2012) $[2 \mathrm{HP}$ (Hydrogen production) $=2 \times \mathrm{C} 2$ $+\mathrm{C} 3+4 \times \mathrm{C} 4+2 \times \mathrm{Ci} 5+2 \times \mathrm{C} 5]$ [2HUS $($ Hydrogen utilization $)=2 \times \mathrm{C} 3+2 \times \mathrm{C} 4+$ C5].

\section{Statistical Analysis}

The ration in this experiment:

$$
\begin{aligned}
\mathrm{A}= & \text { Native grass }(100 \%)+\text { Jengkol peel } \\
& \text { powder }(0 \%) \\
\mathrm{B}= & \text { Native grass }(98 \%)+\text { Jengkol peel } \\
& \text { powder }(2 \%) \\
\mathrm{C}= & \text { Native grass }(96 \%)+\text { Jengkol peel } \\
& \text { powder }(4 \%) \\
\mathrm{D}= & \text { Native grass }(94 \%)+\text { Jengkol peel } \\
& \text { powder }(6 \%)
\end{aligned}
$$

The experiment used randomized block design with 4 treatments $(0 \%, 2 \%, 4 \%$, $6 \%$ and 4 replications. Data were analyzed using One-way ANOVA and Ducan Multiple Range Test examined the differences among treatment means (Steel and Torrie, 1995).

\section{RESULTS AND DISCUSSIONS}

\section{VFA Molar Proportion}

The supplementation of 2-6\% Jengkol peel powder did not affect $(\mathrm{P}>0.05)$ the VFA molar proportion and ratio of acetate 
Table 2. Methane gas production $\left(\mathrm{CH}_{4}\right)$

\begin{tabular}{lc}
\hline Jengkol Peel Powder (\%) & $\mathrm{CH}_{4}(\%)$ \\
\hline 0 & $5.51 \pm 0.73^{\mathrm{c}}$ \\
2 & $2.35 \pm 0.41^{\mathrm{a}}$ \\
4 & $2.60 \pm 0.18^{\mathrm{a}}$ \\
6 & $3.16 \pm 0.23^{\mathrm{b}}$ \\
\hline
\end{tabular}

Note: Means in the same column with different superscript differ significantly $(\mathrm{P}<0.05)$.

Table 3. Hydrogen $\left(\mathrm{H}_{2}\right)$ balance $\left(\mathrm{CH}_{4}\right)$

\begin{tabular}{lcc}
\hline Estimation Model & Jengkol Peel Powder (\%) & $\mathrm{H}_{2}$ \\
\hline \multirow{3}{*}{$\mathrm{H}_{2}$ Production } & 0 & $34.27 \pm 7.04^{\mathrm{b}}$ \\
& 2 & $12.76 \pm 0.83^{\mathrm{a}}$ \\
& 4 & $17.39 \pm 1.18^{\mathrm{a}}$ \\
& 6 & $19.16 \pm 2.56^{\mathrm{a}}$ \\
\hline & 0 & $7.54 \pm 1.58^{\mathrm{b}}$ \\
$\mathrm{H}_{2}$ Utilization & 2 & $2.92 \pm 0.08^{\mathrm{a}}$ \\
& 4 & $4.34 \pm 0.54^{\mathrm{a}}$ \\
& 6 & $3.97 \pm 1.24^{\mathrm{a}}$ \\
\hline
\end{tabular}

Note: Means in the same column with different superscript differ significantly $(\mathrm{P}<0.05)$.

and propionate (Table 1). Proportion of acetate were $68.77 \%-75.86 \%$, propionate were $12.88 \%$ - $14.90 \%$, butyrate were $6.37 \%$ $8.45 \%$, valerate were $4.88 \%-7.87 \%$, and $\mathrm{A} / \mathrm{P}$ ratio were $4.64-6.02$. McDonald et al. (2002) reported that VFA molar proportion strongly influenced by type of feed that consumed. Cattle that consumed the feed with proportion of grass silage produced: acetate (74\%), propionate $(17 \%)$, butyrate $(7 \%)$, and others (3\%); while if the feed consumed was forage and concentrate $(40 \%: 60 \%)$ produced: acetate $(61 \%)$, propionate $(18 \%)$, butyrate $(13 \%)$, and others $(8 \%)$.

The result showed that supplementation Jengkol peel powder until 6\% did not affect pattern of rumen fermentation. Hu et al. (2005) reported that supplementation of saponin extract from tea seed that contain $60 \%$ saponin at $0.4 \mathrm{mg} / \mathrm{ml}$ rumen fluid did not affect on partial and total VFA. Different result was reported by Wina et al. (2005) addition saponin in ration increased propionate proportion and decreased A:P ration.

\section{Methane Gas Production $\left(\mathrm{CH}_{4}\right)$ and Hydrogen Balance}

The supplementation of 2-6\% Jengkol peel powder decreased $(\mathrm{P}<0.05)$ methan gas production and hydrogen production compared with the treatment without supplementation of Jengkol peel powder (Table 2). High hydrogen production was correlated with high methane production. This was presumably because the saponin in Jengkol peel powder could defaunate protozoa so decreased its population and activity from methanogen. Takahashi (2006) reported that defaunation can reduce the symbiosis mechanism between methanogen and protozoa, so just little hydrogen can converted to methane. Protozoa defaunation can reduce methane production linearly with decreasing protozoa and methanogen (Hess et al., 2003) reported that lerak extract that contained saponin can be used as metanogenesis inhibitor that reduced methane production.

Research from Pen etal. (2006), reported thatsupplementationofextract Yuccaschidigera at 2,4 , and $6 \mathrm{ml} / 1$ rumen fluid highly significantly $(\mathrm{P}<0,001)$ decreased methane 
production from $32 \%-42 \%$ and decreased protozoa until $56 \%$. Same result reported by $\mathrm{Hu}$ et al. (2005) supplementation of saponin extract from tea seed that contain $60 \%$ saponin at $0.2-0.4 \mathrm{mg} / \mathrm{ml}$ rumen fluid highly significantly $(\mathrm{P}<0,01)$ decreased protozoa population and methane production.

\section{CONCLUSION}

The research concluded that the supplementation of Jengkol (A. jiringa) peel powder until $6 \%$ decreased methane production and hydrogen balance but did not affect on VFA molar proportion.

\section{ACKNOWLEDGMENTS}

The authors gratefully acknowledge financial support from Directorate General of Higher Education, Ministry of National Education of Indonesia through "PKPT" grant 2018.

\section{REFERENCES}

BPS. 2018. Produksi Jengkol Provinsi Bengkulu. https://www.bps.go.id/site/ resultTab [21 February 2018].

Hess, H. D., M. Kreuzer., T. E. Diaz., C. E. Lascano., J. E. Carulla, and C. R. Soliva. 2003. Saponin rich tropical methanogenesis in faunated and fruits affect fermentation and defaunated fluid. J Anim Feed Sci Technol. 109: 79-94.

Hidayah, N. and Suliasih. 2017. Potential of Bioactive Compounds Archidendron jiringa by Product to be Natural Feed Additive for Sustainable Animal Production. Proceeding International Seminar SAADC. Fakultas Peternakan, Universitas Brawijaya Malang.

Holtshausen, L., A. V. Chaves., K. A. Beauchemin., S. M. McGinn., T. A. McAllister., P. R. Cheeke, and C. Benchaar. 2009. Feeding saponin- containing Yucca schidigera 207 and Quillaja saponaria to decrease enteric methane production in dairy cows. J of Dairy Scie. 92: 2809-2821.

Hu., W. Wei-lian., L. Yue-ming., G. Jianxin., Yanqiu, and Y. Jun-an. 2005. Tea saponins affect in vitro fermentation and methanogenesis in faunated and defaunated rumen fluid. J Zhejiang Univ Sci. 6: 787-792.

Jayanegara, A., E. Wina., C. R. Soliva., S. Marquardt., M. Kreuzer, and F. Leiber. 2011. Dependence of forage quality and methanogenic potential of tropical plants on their phenolic fractions as determined by principal component analysis. Anim Feed Sci Technol. 163: 231-243.

McDonald, P., R. A. Edward., J. F. D. Greenhalgh, and C. A. Morgan. 2002. Animal Nutrition 6th Edition. Scientific and Tech John Willey \& Sons. Inc. New York.

Mitsumori, M., T. Shinkai., A. Takenaka., O. Enishi., K. Higuchi., Y. Kobayashi., I. Nonaka., N. Asanuma., S. E. Denman, and C. S. McSweeney. 2012. Responses in digestion rumen fermentation and microbial populations to inhibition of methane formation by a halogenated methane analogue. British J Nutr. 108: 482-491.

Moss, A. R., J. P. Jouany, and J. Newbold. 2000. Methane Production by Ruminants: Its contribution to global warming. Annal Zootechnology. 49: 231-253.

Pen, B., C. Sar., B. Mwenya., K. Kuwaki., R. Morikawa, and J. Takahashi. 2006. Effects of Yucca schidigera and Quillaja saponaria extracts on in vitro ruminal fermentation and methane emission. J Anim Feed Sci and Tech. 129: $175-186$.

Steel, R. G. D. and J. H. Torrie. 1995. Prinsip dan Prosedur Statistik Suatu Pendekatan Biometrik. PT. Gramedia Pustaka Utama. Jakarta 
Takahashi, J. 2006. Greenhouse gases emission and sustainable development of animal agriculture. http://ir.obihiro. ac.jp/dspace/bitstre am.pdf [16 October 2012]

Tilley, J. M. A. and R. A. Terry. 1963. A twostage technique for the in vitro digestion of forage crops. J British Grasslan Soc. 18: 104-111.

Wanapat, M., A. Cherdthong., K. Phesatcha, and S. Kang. 2013. Dietary sources and their effects on animal production and environmental sustainability. Anim Nutr. 1: 96-103.

Wina, E., S. Muezel., E. Hoffman., H. P. S. Makkar, and K. Becker. 2005. The impact of saponin-containing plant materials on ruminant production A Review. J Agricultural and Food Chemistry. 53: $8093-8015$. 